\title{
Treatment of Mooren's ulcer with cyclosporin A: report of three cases
}

\author{
JOHN C HILL ${ }^{1}$ AND PAUL POTTER ${ }^{2}$ \\ From the 'Departments of Ophthalmology and ${ }^{2}$ Clinical Science and Immunology, University of Cape Town \\ and Groote Schuur Hospital, Cape Town, South Africa
}

SUMmaRY Three patients with severe, bilateral, progressive Mooren's ulcers, unresponsive to medical and surgical therapy, were treated with cyclosporin A. All three responded rapidly to the drug and there has been no recurrence of the Mooren's ulcers since (average follow-up 14 months). Peripheral blood $\mathrm{T}$ lymphocyte subsets were estimated prior to and during treatment. No significant abnormalities were found initially. Suppressor cells increased on treatment, and a corresponding drop of the helper/suppressor cell ratio occurred in two patients.

Mooren's ulcer is a chronic painful ulceration of the corneal periphery. There is a steep, undermined leading edge to the ulcer, which spreads both circumferentially and centrally, eventually involving the whole cornea. Clinically, two different types of Mooren's ulcer have been recognised. ${ }^{12} \mathrm{~A}$ limited type occurs unilaterally in older patients; progression can be halted by various surgical treatments, including conjunctival excision and lamellar keratoplasty. The other type of Mooren's ulcer is relentlessly progressive, often bilateral, and occurs in younger patients, particularly males. There is involvement of the sclera as well as peripheral cornea, perforation occurs more commonly, and both surgical and medical treatments are unsatisfactory, with the ultimate prognosis being poor. ${ }^{1}$

The aetiology of Mooren's ulcer is unknown, but recent evidence suggests an autoimmune process is responsible. Circulating antibodies to human corneal and conjunctival epithelium have been found in a patient with Mooren's ulcer. ${ }^{34}$ Histologically the conjunctiva is found to be heavily infiltrated with plasma cells and lymphocytes. ${ }^{2}$ Direct immunofluorescent techniques have demonstrated immunoglobulin localised to the conjunctival epithelium, complement also being found in active cases. ${ }^{4}$ The presence of collagenolytic and probably proteoglycanolytic enzymes in the conjunctiva adjacent to the Mooren's ulcer indicates that this tissue is intimately associated with the pathogenesis. ${ }^{5}$ The Correspondence to Dr J C Hill, Department of Ophthalmology, Medical School, Observatory 7925, Cape Town, South Africa. source of these enzymes is probably from mononuclear cells and neutrophils found in and around the ulcerating tissues. ${ }^{56}$

Evidence that cellular as well as humoral autoimmune phenomena are found in Mooren's ulcer has been demonstrated by positive macrophage migration inhibition in response to corneal antigen presentation to lymphocytes from patients with the disease. ${ }^{7}$ Murray and Rahi ${ }^{8}$ found a deficiency of suppressor T lymphocytes in the peripheral blood of a patient with Mooren's ulcer. They postulated that this deficit in the immunoregulatory mechanism explains some of the immunological abnormalities reported in previous studies and also provides additional evidence for an autoimmune aetiology. Furthermore an increase in circulating immune complexes in patients with Mooren's ulcer has been reported. ${ }^{9}$

The presumed autoimmune aetiology and the poor response to conventional treatment, especially of the progressive type of Mooren's ulcer, has led to the use of immunosuppressives in an attempt to control the disease. Foster et . ${ }^{6}{ }^{6}$ used methotrexate for six weeks in one patient with a good response, and no recurrence occurred during the subsequent 12 months. The authors suggested immunosuppressives should be given early in the disease. In a second patient Foster ${ }^{10}$ reported only partial success with this agent and cyclophosphamide was then used. However, recurrence occurred when the dose of this drug was reduced after six months.

Murray and Rahi ${ }^{8}$ suggested that treatment should 
be directed towards correction of the T lymphocyte helper/suppressor ratio by giving one of the thymic hormones or alternatively cyclosporin A (CSA). This paper presents three patients with the progressive type of Mooren's ulcer who were treated with CSA successfully.

\section{Patients and methods}

Three patients with severe bilateral Mooren's ulcers of the progressive type, were treated with CSA (Table 1). All were unresponsive to conventional therapy. Initially topical antibiotics and acetyl cysteine $10 \%$ were given. When these failed to halt the disease topical corticosteroids were administered, and finally conjunctival peritomy and cryotherapy were performed to the conjuctiva adjacent to the ulcer. These surgical measures provided some temporary relief, but within a week the ulcers progressed again. Before administration of CSA two eyes perforated. An onlay lamellar graft was performed on one; the other perforation was sealed with cyanoacrylate glue. After failure of the above regimen oral CSA was started.

The patients were all healthy black males with no systemic disease. No biochemical abnormalities were detected on screening; in particular serum creatinine, urea, and liver function tests were normal. Urine analysis and creatinine clearances were also normal. Initially CSA was given as a loading dose of $8 \mathrm{mg} / \mathrm{kg} /$ day in two divided doses for two days. Thereafter, the dose was reduced to $3-4 \mathrm{mg} / \mathrm{kg} / \mathrm{day}$, the dose being adjusted to maintain trough serum levels of 200-400 $\mathrm{ng} / \mathrm{ml}$. Biweekly tests of trough serum CSA levels, serum creatinine, urea, and liver function were performed. Creatinine clearance was tested weekly.

During CSA treatment all other medication was stopped except topical antibiotics. Before and during the course of treatment the following immunological parameters were investigated. $T$ lymphocyte subsets were measured on a fluorescence activated cell sorter, immunoglobulins and complement $\mathrm{C} 3$ and $\mathrm{C} 4$

Table 1 Clinical details of patients

\begin{tabular}{|c|c|c|c|c|c|}
\hline & $\begin{array}{l}\text { Age } \\
\text { (years) }\end{array}$ & $\begin{array}{l}\text { Duration } \\
\text { of disease } \\
\text { prior to } \\
\text { CSA } \\
\text { (weeks) }\end{array}$ & $\begin{array}{l}\text { Period of } \\
\text { CSA } \\
\text { therapy }\end{array}$ & $\begin{array}{l}\text { Follow- } \\
\text { up } \\
\text { (months) }\end{array}$ & Remarks \\
\hline Case 1 & 62 & 7 & 6Weeks & 16 & $\begin{array}{l}\text { Free from } \\
\text { Mooren's ulcer }\end{array}$ \\
\hline Case 2 & 65 & 5 & 6 Weeks & 12 & $\begin{array}{l}\text { Free from } \\
\text { Mooren's ulcer }\end{array}$ \\
\hline Case 3 & 58 & 8 & 5.5 Months & 14 & $\begin{array}{l}\text { Free from } \\
\text { Mooren's ulcer, } \\
\text { Graft clear }\end{array}$ \\
\hline
\end{tabular}

were measured by nephelometry, and immune complexes were estimated by the Clq binding assay. All the patients lived in rural areas and were admitted to hospital for treatment. CSA was tailed off and stopped after six weeks, and two of the patients were discharged. Case 3, who was monocular, elected to remain in hospital to have a corneal graft (see below).

\section{Results}

\section{CASE 1}

A 62-year-old man presented with a three-week history of excruciating pain. $\mathrm{He}$ had bilateral Mooren's ulcers involving $160^{\circ}$ and $130^{\circ}$ of the right and left corneal peripheries respectively. Centrally the corneas were clear, with visual acuities of $6 / 9$ right and $6 / 6$ left. The ulceration continued to progress on medical therapy and was only temporarily halted by conjunctival peritomy and cryotherapy. The pain continued unabated. CSA was started. Within three days the pain had completely subsided, and by the end of the first week the ulcers ceased progressing. At one month the eyes were quiet, the ulcers had partially filled in, and an intact epithelial layer was present. Treatment was tailed off and stopped after six weeks. The Mooren's ulcers have not recurred in the 16-month follow-up. His visual acuities are 6/6 right and left corrected.

\section{CASE 2}

A 65-year-old man presented with severe pain and loss of vision in both eyes of one month's duration. His visual acuity was hand movements in both eyes. Bilateral $360^{\circ}$ ring Mooren's ulcers were present with central islands of scarred cornea (Fig. 1). The left eye had perforated inferiorly; cyanoacrylate glue was applied to seal the leak. Medical treatment was instituted, but because of the danger of further perforation bilateral $360^{\circ}$ conjunctival peritomy and cryotherapy was performed. This gave temporary relief, but within a week the ulceration was again progressing. CSA was started, and within four days the pain had subsided and by a week the ulcers had stopped progressing. At a month his eyes were quiet and the ulcers had partially filled in, with an intact epithelial layer. After six weeks the CSA was tailed off and stopped. Eleven months later he remained free of disease, but his corneas were opaque and vascularised (Fig. 2). A right combined keratoplasty and lens extraction was performed.

\section{CASE 3}

A 58-year-old man was seen with a phthisical right eye. He gave a history highly suggestive of an old perforated Mooren's ulcer. His left eye had become painful a month previously, and his vision had 


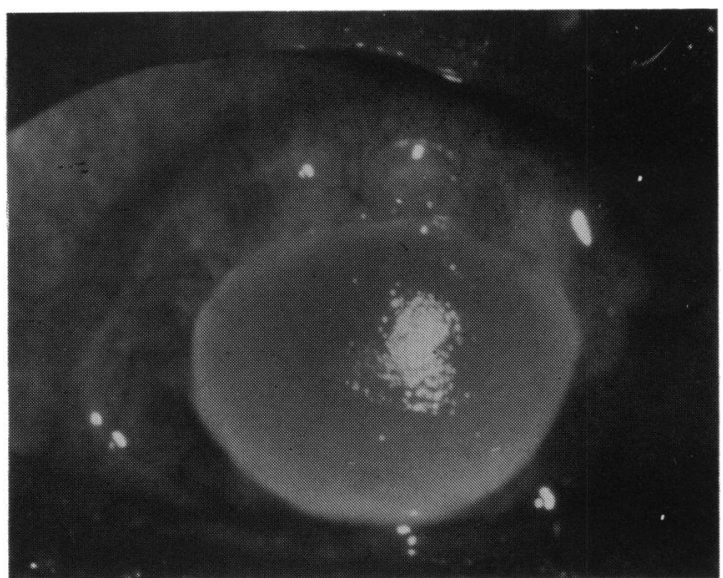

Fig. 1 Case 2, Mooren's ulcer involving the entire corneal periphery of the right eye. The central cornea is opaque.

deteriorated to hand movements. There was a $270^{\circ}$ Mooren's ulcer with a perforation. The central cornea was opaque. A patch lamellar graft was applied and topical medication started. During the next two weeks the ulcer progressed to a ring ulcer, and the graft was absorped. Conjunctival peritomy and cryotherapy provided some respite, but within a week the disease was again progressing. CSA was started, and by the third day the pain had gone and by a week the ulcer was healing. After one month the eye was quiet, with the ulcer partially filled in with an intact epithelial layer. The central cornea remained opaque, and at six weeks he elected to remain in hospital for a central corneal graft. CSA was continued, and prednisone $25 \mathrm{mg}$ daily was started to prevent rejection of the graft in this highly vascular-

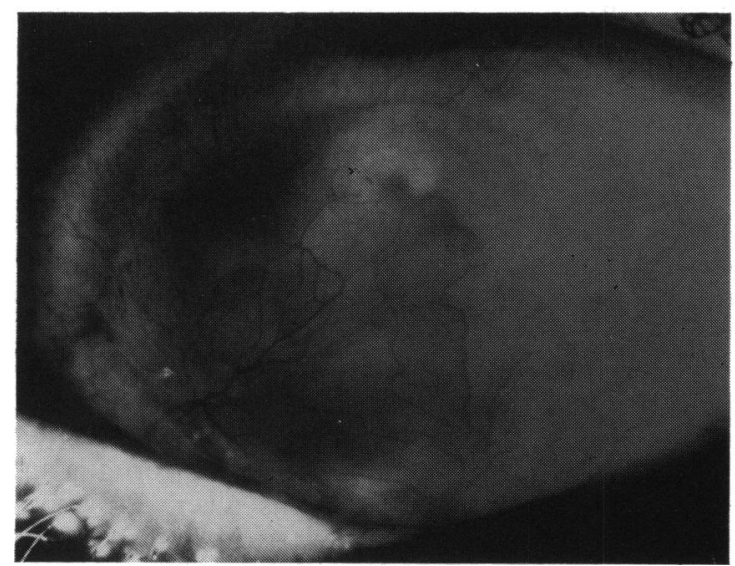

Fig. 2 Same eye as in Fig. 111 months later. The eye is quiet, the ulcers have filled in, but the cornea is opaque and vascularised. ised corneal bed. CSA and prednisone were tailed off and stopped four months postoperatively. When seen 14 months later his graft remained clear, his visual acuity was $6 / 12$ corrected, and there had been no recurrence of his Mooren's ulcer.

Within four days of starting CSA treatment all three patients were free from pain. By the end of the first week the ulcers had stopped progressing and showed evidence of healing. After four weeks all the eyes were quiet, the stroma comprising the base of the ulcer was thicker, and, although furrows remained, an intact epithelial layer was present. All the eyes have remained quiet and free from a recurrence of Mooren's ulcer and the corneal graft in case 3 remains clear. The average follow-up is 14 months (range 12-16 months).

\section{HISTOLOGY AND BIOCHEMISTRY}

Histological examination of the excised conjunctiva from all three patients revealed findings consistent with a diagnosis of Mooren's ulcer. ${ }^{56}$ In all specimens neutrophils, lymphocytes, and large numbers of plasma cells were present in the subepithelial layers.

The serum IgA was raised (Table 2) in all three patients. This is in keeping with other studies that have reported raised levels of $\operatorname{IgA}$ in Mooren's ulcer. ${ }^{112}$ In case 2 the level 11 months after treatment was reduced but still above the normal range, despite his being clinically free of the disease. Case 3 showed decreasing values of $\operatorname{IgA}$ while on cyclosporin. IgM levels were normal in all our patients. Cases 1 and 3 had normal IgG values, but in case 2 it was raised. No significant abnormalities were found in the level of complement values $\mathrm{C} 3$ and $\mathrm{C} 4$. Circulating immune complexes were normal in all three patients.

Estimations of total T lymphocytes (OKT 3, Ortho Diagnostics) were within the normal range in all patients (Table 2). Helper T cells (OKT 4) were also within normal limits. Suppressor T cells (OKT 8) were in the normal range initially and rose during CSA treatment. The rise was most marked in case 3 . The helper/suppressor ratio was initially normal in all three patients and dropped in cases 1 and 3; the change was more marked in the latter. In case 2 the ratio remained essentially constant during treatment and 11 months later.

No significant side effects of treatment were encountered. Serum creatinine and urea rose in all three patients but did not exceed the upper limits of normal. Dosage of CSA was adjusted to keep serum levels within the therapeutic range, without allowing creatinine to rise excessively. No abnormalities in liver enzymes or blood cell counts were detected. Creatinine clearances dropped but again remained within normal limits in all three patients. Other 
Table 2 Immunological parameters

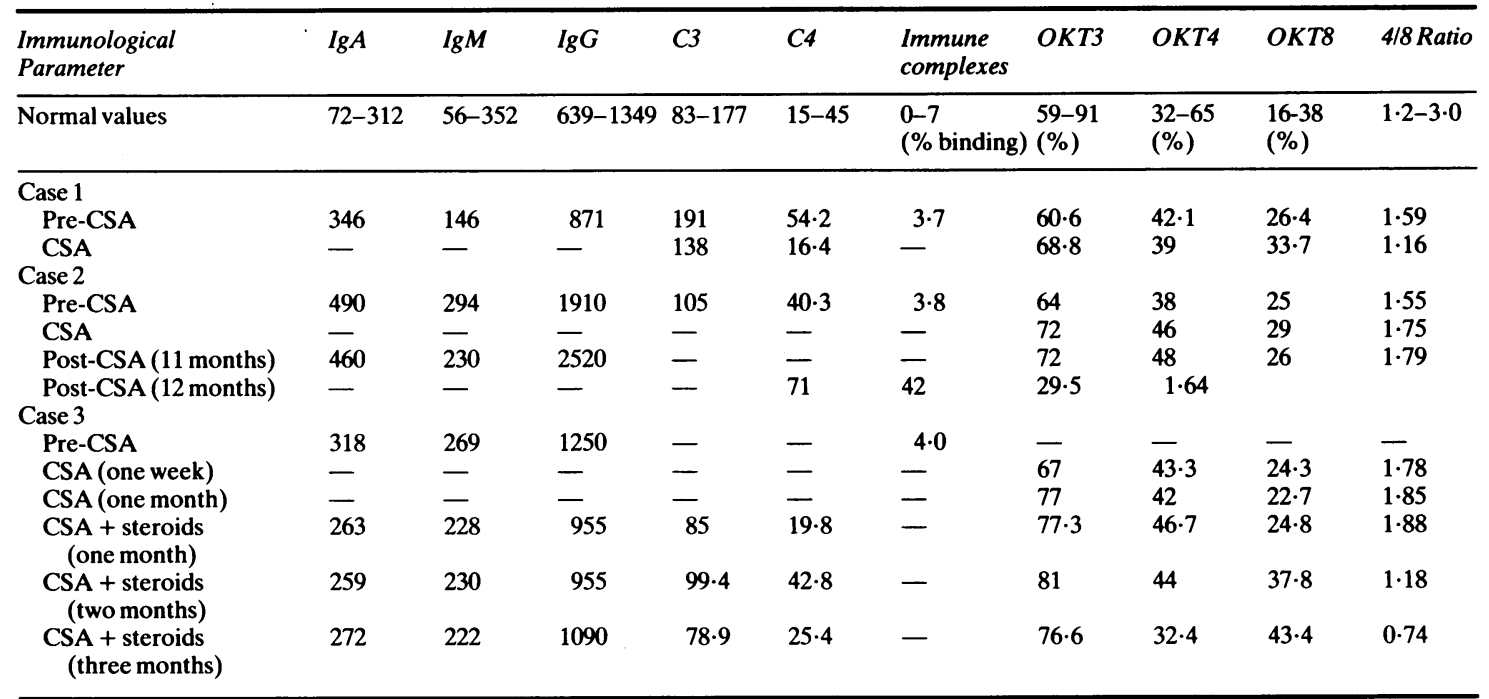

known side effects of CSA therapy such as neuraesthesia, gum hypertrophy, tremor, or lymphoma did not occur.

\section{Discussion}

Our patients, all black males, had clinical and histological evidence of Mooren's ulcer. Standard medical and surgical treatments had failed to halt the disease. In all the cases the disorder was bilateral, one patient having lost an eye. In another two eyes perforation occurred-a total of three perforations in the six eyes $(50 \%)$. The disease was undoubtedly of the serious, progressive type that is resistant to treatment, though our patients were older than people in whom the progressive type usually occurs. ${ }^{1213}$ None of the patients had evidence of anklyostomiasis, a disease implicated in the high incidence of the progressive type of Mooren's in other parts of Africa. ${ }^{213}$

All our patients had raised IgA levels. Mondino et al. ${ }^{11}$ and Mondino ${ }^{12}$ found $56 \%$ and $63 \%$ respectively of their patients with Mooren's ulcer had raised levels of this immunoglobulin. Immune complexes were found to be normal by the CIq binding assay. This is in keeping with the finding by Berkowitz et al. ${ }^{10}$ of normal levels in patients in Mooren's ulcer using this assay, though higher levels were found using the Raji cell assay.

The totals of $\mathrm{T}$ lymphocytes were in the normal range. Similarly the helper cells showed normal values. Towards the end of the longer period of CSA therapy given to case 3 the level dropped significantly. The most consistent response to treatment was observed in the level of suppressor cells, which rose in all patients. This is the expected response to CSA treatment. A drop in the helper/suppressor ratio was found in cases 1 and 3 . In case 2 the helper cells increased, as did the ratio. None of our patients had low levels of suppressor cells initially, in contrast to the findings of Murray and $\mathrm{Rahi}^{8}$ in their patient. The most marked changes in the lymphocyte subsets were found in case 3 , who had a longer course of CSA therapy. These changes occurred when corticosteroids were introduced after his keratoplasty, and may be partly explained by a potentiating effect of steroids on CSA.

The most dramatic effects of CSA treatment were clinical. Within four days all three patients were free from pain and remained so. This was in contrast to the medical and surgical treatments that did not relieve the pain that had been present from five to eight weeks prior to CSA therapy.

The effect on the ulcer was no less dramatic. Within a week the ulcers stopped progressing and the eyes were quieter. After four weeks the eyes were not inflamed and the ulcers had partly filled in, leaving shallow furrows with intact epithelial coverings. No recurrence has followed the stopping of CSA (average follow-up 14 months).

The poor response to other treatments and the rapid response to CSA suggests that this drug is an effective treatment for Mooren's ulcer. Provided improvement occurs as rapidly as in our patients, a six-week course appears to be sufficient to halt the disease and prevent recurrence, as shown by cases 1 and 2 . Its mode of action is not entirely clear. 
We were unable to demonstrate a deficiency of suppressor cells in our patients.

CSA inhibits the activation of the helper (OKT4) subset but does not inhibit the activation of suppressor cells (OKT8). This differential effect on different $T$ cell subsets results in a fall in the OKT4:8 ratio during treatment. Because 'help' is required for the activation of the cytotoxic subset the drug secondarily inhibits cytotoxic cell formation. ${ }^{14}$ CSA also inhibits the pathway of primary $\mathrm{T}$ cell activation by interfering with the transmission of the antigen specific signal to the interior of the cell, following antigen binding. ${ }^{\text {is }}$ The efficacy of CSA in animal models of autoimmune diseases has been summarised by Borel. ${ }^{16}$ While some animal models of autoimmunity were improved by CSA therapy, others deteriorated. Published studies of the efficacy of CSA in human autoimmune diseases are limited, but promising results have been obtained in some cases, including the use of CSA in Graves's ophthalmopathy ${ }^{17}$ and uveitis. ${ }^{18} 19$ There are no other published studies on the efficacy of CSA in the treatment of Mooren's ulcer.

CSA is a potent drug with potentially severe side effects including nephrotoxicity, hepatotoxicity, and occurrence of lymphoma. A recent report ${ }^{20}$ indicates that nephrotoxicity may be avoided by monitoring serum creatinine and trough CSA blood levels, with corresponding adjustments of the administered dose. By taking these precautions, and also performing serial tests of liver function and creatinine clearance, side effects can be kept to a minimum. The risk of neoplasia with CSA appears to be no greater than with other immunosuppressive regimens. ${ }^{21}$ Apart from small increases in serum urea and creatinine, which remained within normal limits, no side effects were encountered in this study.

Mooren's ulcer is a sight threatening disease, especially when progressive and bilateral. The associated pain is also severe. Under these conditions immunosuppression is justified if the drug is carefully monitored and side effects can be prevented or minimised. In our three patients CSA appeared to be effective, but this is a very small study. To prove its efficacy a larger, controlled trial will be necessary. However because Mooren's ulcer is a rare disorder a trial of this type may be difficult to organise.

\footnotetext{
We thank Dr H Reeve Sanders, Chief Medical Superintendent, for permission to publish, and Miss $\mathrm{N}$ van Vuuren for preparation of this manuscript.
}

\section{References}

1 Wood TO, Kaufman HE. Mooren's ulcer. Am J Ophthalmol 1971; 71: 417-22.

2 Kietzman B. Mooren's ulcer in Nigeria. Am J Ophthalmol 1968; 65: 679-85.

3 Schaap OL, Feltkamp TEW, Breehart AC. Circulating antibodies to corneal tissue in a patient suffering from Mooren's ulcer (ulcus rodens corneae). Clin Exp Immunol 1969; 5: 365-72.

4 Brown SL, Mondino BJ, Rabin BS. Autoimmune phenomena in Mooren's ulcer. Am J Ophthalmol 1976; 82: 835-40.

5 Brown SL. Mooren's ulcer: histopathology and proteolytic enzymes of adjacent conjunctiva. Br J Ophthalmol 1975; 59: 670-4.

6 Foster CS, Kenyen KR, Greiner J, Greineder DK, Friedland B, Allansmith MR. The immunopathology of Mooren's ulcer. Am J Ophthalmol 1979; 88: 149-59.

7 Mondino BJ, Brown SI, Rabin BS. Cellular immunity in Mooren's ulcer. Am J Ophthalmol 1978; 85: 788-91.

8 Murray PI, Rahi AHS. Pathogenesis of Mooren's ulcer: some new concepts. Br J Ophthamol 1984; 68: 182-7.

9 Berkowitz PJ, Arentsen JJ, Felberg NT, Laibson PR. Presence of circulating immune complexes in patients with peripheral corneal disease. Arch Ophthalmol 1983; 101: 242-5.

10 Foster CS. Immunosuppressive therapy for external ocular inflammatory disease. Ophthalmology (Rochester) 1980; 87: 140-9.

11 Mondino BJ, Brown SI, Rabin BS. Autoimmune phenomena of the external eye. Ophthalmology (Rochester) 1978; 85: 801-17.

12 Mondino BJ. Autoimmune phenomena in ocular cicatricial pemphigoid, Mooren's ulcer and Sjögren's syndrome. In: Helmsen RJ, Suran A, Gery I, eds. Proceedings of immunology of the eye: Workshop: II. Immunology Abstracts, special suppl 1981: 77-89.

13 Stilma JS. Conjunctival excision or lamellar scleral autograft in 38 Mooren's ulcers from Sierra Leone. Br J Ophthalmol 1983; 67: 475-8.

14 Bunjes D, Hardt C, Röllinghoff M, Wagner H. Cyclosporin A mediates immunosuppression of primary cytotoxic $\mathrm{T}$ cell responses by impairing the release of interleukin 1 and interleukin 2. Eur J Immunol 1981; 11: 657-61.

15 Andrus L, Prowse SJ, Lafferty, KJ. Interleukin 2 production by both Ly $2+$ and Ly $2-T$ cell subsets. Scand J Immunol 1981; 13: 297-301.

16 Borel JF. Cyclosporin: historical perspectives. Transplant Proc 1983; 15: (suppl 1-2): 2219-29.

17 Weetman AP, Ludgate M, Mills PV, et al. Cyclosporin improves Graves's ophthalmopathy. Lancet 1983; ii: 486-9.

18 Nussenblatt RB, Rook AH, Walker WB, Palestine AG, Scher I, Gery I. Treatment of intraocular inflammatory disease with cyclosporin A. Lancet 1983; ii: 235-8.

19 Nussenblatt RB, Palestine AG, Chan C. Cyclosporin A therapy in the treatment of intraocular inflammatory disease resistant to systemic corticosteroids and cytotoxic agents. Am J Ophthalmol 1983; 96: 275-82.

20 Hows JM, Chipping PM, Fairhead S, Smith J, Bingham A, Gordon Smith EC. Nephrotoxicity in bone marrow transplant recipients treated with cyclosporin A. Br J Haematol 1984; 54: 69-78.

21 Editorial. Cyclosporin and neoplasia. Lancet 1983; i: 1083.

Accepted for publication 17 April 1986. 